\title{
Reconstruction of occupational mercury exposures at a chloralkali plant
}

\author{
P L Williams, H Frumkin, M L Pierce, C C Manning, L Elon, A G Sanders
}

\begin{abstract}
Objective-To reconstruct historical workplace exposure to mercury $(\mathrm{Hg})$ from 1956 to 1994 at a large chloralkali factory for use in a current epidemiology study of the factory.

Methods-All job activities of the employees were classified into one of 16 exposure categories, and the dates of changes in the processes were identified. Exposures to $\mathrm{Hg}$ for each job category, at each period of the plant's operation, were then reconstructed from several data sources. A jobtime period-exposure matrix was created, and the individual exposures of former workers were calculated. Data on exposure to $\mathrm{Hg}$ in air were compared with modelled concentrations of $\mathrm{Hg}$ in air and data on urinary $\mathrm{Hg}$ of the employees.

Results-Within an exposure category, concentrations of $\mathrm{Hg}$ in air were fairly constant for the first 20 years of the factory's operation, but began to increase in the late 1970s. Employees working in the cell room had the greatest exposures to $\mathrm{Hg}$. The exposure estimates had significant correlations $(p<0.001)$ with the urinary data and were well within the modelled range of concentrations of $\mathrm{Hg}$ in air.

Conclusions-The highest exposures occurred from 1987 until the plant closed in early 1994 with some exposure categories having time weighted average exposures to $\mathrm{Hg}$ greater than $140 \mu \mathrm{g} / \mathrm{m}^{3}$.

(Occup Environ Med 2001;58:81-86)
\end{abstract}

Keywords: mercury; chloralkali; occupational exposure; job exposure matrix

Environmental and

Occupational Health,

Rollins School of

Public Health of

Emory University,

Atlanta, GA 30322,

USA

H Frumkin

A G Sanders

Department of

Biostatistics

C C Manning

L Elon

Glynn County Health Department,

Brunswick, GA 31520,

USA

M L Pierce

Correspondence to: Dr P Williams

pwilliam@arches.uga.edu

Accepted 22 September 2000

This paper describes the historical reconstruction of exposure to $\mathrm{Hg}$ among employees at a chloralkali plant that operated from 1956 to 1994 in Brunswick, Georgia, USA. Although caustic soda and chloride production using the chloralkali process has a long history, few studies have measured occupational exposures to $\mathrm{Hg}$. This study involved the development of a job-exposure matrix based on historical workplace measurements. The exposure estimates from the matrix were validated with two independent strategies: estimating concentrations of $\mathrm{Hg}$ in air by modelling rates of change of room air and known $\mathrm{Hg}$ losses within the factory; and comparing data on urinary $\mathrm{Hg}$ concentrations of the employees with predicted concentrations of $\mathrm{Hg}$ in air. Also, the exposure estimates from the matrix were compared with exposure estimates from previous studies of chloralkali plants. Finally, the reconstructed data on exposure to $\mathrm{Hg}$ were used in a historical cohort study of the workforce, the results of which are reported separately. ${ }^{1}$

From 1956 to the end of 1994, a large chloralkali production factory operated in Brunswick, Georgia, USA. The plant was situated on a 550 acre marshy site adjacent to the mouth of the Turtle River as it empties into the Atlantic Ocean. The factory used electrolytic cells based on $\mathrm{Hg}$ (Solvay process) located in two large cell rooms to convert sodium chloride and water into chlorine, caustic soda (or soda ash), hydrochloric acid, and hydrogen gas. This operation resulted in considerable releases of $\mathrm{Hg}$ into the workplace and the ambient environment leading the Georgia Environmental Protection Division to close several adjacent waterways to fishing in the early 1990s. In February 1994, the Georgia Environmental Protection Division revoked the factory's National Pollutant Discharge Elimination System and air quality permits, and the plant ended operations. The site was subsequently designated a Superfund hazardous waste site by the United States Environmental Protection Agency, and extensive remediation efforts were completed during the late 1990s.

Concerns about the health of employees related to exposure to $\mathrm{Hg}$ began to surface in the middle to late 1980 s and several investigations were performed to assess exposures of employees. It was later learned that over $227000 \mathrm{~kg} \mathrm{Hg}$ used at the site were unaccounted for and may have been lost to the environment. In response to local concerns, an epidemiological study of the former employees was initiated in 1997, with funding from the United States National Institute for Environmental Health Sciences.

\section{Materials and methods}

SAMPLING DATA ON Hg IN AIR

Sampling data on $\mathrm{Hg}$ in air were collected at nel routinely collected $\mathrm{Hg}$ vapour readings and recorded the air concentrations on a standard form that provided a sketch of the area with the sample, location, and date. This sampling was performed throughout both floors of the two cell rooms and occasionally in other areas including the lunch room, locker room, laundry area, Hg still area, and products area. These were area samples, not personal samples, collected with a hand held Bacharach Mercury Sniffer. Air sampling forms were found for 488 separate days of exposure between 1967 and 1993, representing about 25000 separate readings of concentrations of $\mathrm{Hg}$ in air. the plant from several sources. Factory person- 
Table 1 Chloralkali facility job titles grouped into similar categories of exposure to $\mathrm{Hg}$

\begin{tabular}{ll}
\hline Exposure group & fob titles included \\
\hline Mercury handler & Mercury handler \\
Cell repair & Cell repair, cell assembly \\
Cell room & Assistant cell operator, assistant foreman, cell operator \\
Cell room: others & Shift foreman, tester, engineer, production specialist \\
Products area & Acid loader, bleach operator, products operator, assistant products operator \\
Brine area & Salt plant operator, brine processor or assistant, saturation operator \\
Welding area & Cell welder \\
Machinist & Machinist \\
Mechanics or maintenance & Electrician, maintenance painter, maintenance foreman, instrument technician, laundry room \\
& attendant \\
Relief operators & Relief operator, adjuster, utility operator \\
Broiler room & Broiler room operator \\
Management & Plant manager, operations manager \\
General labourer & Storeroom attendant, laboratory technician, tank car painter, tank car service \\
Plant office & Maintenance clerk, shipping foreman, production supervisor, technician supervisor, security, \\
Main office & maintenance planners, production manager, production superintendent \\
& Employee relations manager, plant controller, senior clerk, payroll clerk, accounting clerk, \\
purchasing agent, receptionist, switchboard operator, purchasing clerk, senior laborer, dock \\
Environmental operator & operator \\
\hline
\end{tabular}

Two federal agencies, the National Institute for Occupational Safety and Health (NIOSH) and the Occupational Safety and Health Administration (OSHA), performed $\mathrm{Hg}$ air sampling within several areas of the factory. A NIOSH health hazard evaluation ${ }^{2}$ was performed in late 1987 to the end of April 1988, and OSHA inspections were conducted in 1988, 1990, and 1992..$^{3-5}$ Finally, scientists from Duke University performed a personal air sampling study at the site in $1988 .{ }^{6}$ These three sources (NIOSH, OSHA, and Duke) yielded a total of 48 personal samples of $\mathrm{Hg}$ in air over 15 days.

\section{EMPLOYEE INTERVIEWS}

Ten former employees of the factory who had experience in all aspects of plant operations from 1956 to 1994 were extensively interviewed. They represented management, supervisory, and union positions. All but one of the people had worked at the site for over 20 years and collectively they had about 250 years of experience at the factory. The individual interviews ranged in duration from 1 hour to several days and assisted in interpreting the factory records previously described. The interviewees provided details on historical changes within the factory and the work practices (use of personal protective equipment, time spent in job duties, activities performed, etc) for each job title.

RECONSTRUCTION OF EXPOSURE

From the interviews and a review of personal records, 55 job titles were identified. Based on a comparison of potential exposures to $\mathrm{Hg}$ from specific work activities, these job titles were grouped into 16 exposure groups (table 1). Extensive estimates were made for the amount of time people in each exposure group spent in specific areas of the factory. This location specific information on duration of exposure was used to derive time weighted average (TWA) formulas for exposure to $\mathrm{Hg}$ for specific exposure groups that allowed the area readings for $\mathrm{Hg}$ to be used to estimate individual exposures.

For each exposure group the TWA formulas were used for each day that sampling data existed and then all the values for a year were averaged to derive an estimated concentration of $\mathrm{Hg}$ in air for a specific year. For the years before the collection of any sampling data of $\mathrm{Hg}$ in air (1956-66), the mean concentration of $\mathrm{Hg}$ in air from 1967-74 was used, based on employee reports that the production process and work practices had not changed appreciably from the 1950 s to the early 1970s. For other years for which no readings of $\mathrm{Hg}$ in air were available (1975-7, 1981-6, and 1989), we interpolated from the earlier and later years based on employee accounts of factory conditions (maintenance, production levels, operating conditions, controls in place) during those years.

We created a matrix that provided the estimates of exposure to $\mathrm{Hg}$ for each exposure group (table 1) for each year from 1956 to the end of February 1994. Personnel records that provided the dates for each job title that the person held were obtained for all former workers. For each former worker participating in the epidemiology study, we combined these two data sources by creating an individual matrix that accounted for each job held from the first to the last, with the associated exposure level for each. For each person, we could then calculate the cumulative exposure, the mean exposure, and the peak exposure, with a computer program written for this purpose. These metrics were used in the epidemiological study.

DATA VALIDATION

We assessed the estimates of exposure to $\mathrm{Hg}$ generated by this process in two ways. Firstly, we compared them with predicted concentrations of $\mathrm{Hg}$ in air in the cell rooms that we calculated based on rates of change and losses of $\mathrm{Hg}$ in air. Secondly, we compared them with personal data on urinary $\mathrm{Hg}$.

The dimensions and equipment space of the two cell rooms were known, permitting calculation of the air volume of each floor. From employee interviews, we collected information on the ventilation design specifications of the building and the conditions of operation. The factory's Environmental Protection Division air permit allowed the release of $2.27 \mathrm{~kg}$ $\mathrm{Hg}$ /day. The factory's engineering staff, 
Table 2 Comparison of concurrent direct reading and active air sampling data for the same exposure category

\begin{tabular}{lll}
\hline Date (separate days) & $\begin{array}{l}\text { Predicted TWA from direct reading } \\
\text { instrument }\left(\mu \mathrm{Hg} / \mathrm{m}^{3} \text { air }\right)\end{array}$ & $\begin{array}{l}\text { Active personal sampler } \\
\left(\mu \mathrm{gg} / \mathrm{m}^{3} \text { air }\right)\end{array}$ \\
\hline April 1988 & 9 & 44 \\
April 1988 & 29 & 30 \\
April 1988 & 33 & 45 \\
April 1988 & 45 & 57 \\
September 1988 & 53 & 223 \\
September 1988 & 61 & 165 \\
September 1988 & 97 & 140 \\
September 1988 & 97 & 234 \\
\hline
\end{tabular}

through a mass balance approach, had calculated that about $1.13 \mathrm{~kg} \mathrm{Hg}$ were lost to the ambient environment through the boiler, and that the rest (about $1.14 \mathrm{~kg} \mathrm{Hg}$ ) was released into each cell room $(0.57 \mathrm{~kg} \mathrm{Hg} /$ cell room). It was assumed that these $\mathrm{Hg}$ losses were uniform over a 24 hour day throughout each cell room. From the room volume and the exhaust capacity of the fans operating within each cell room, the total volume of air exchanged within each room could be calculated. The ranges of concentrations of $\mathrm{Hg}$ were modelled for different seasons of the year based on typical exhaust fan operations and compared with those predicted from the TWA formulas.

As well as data from sampling $\mathrm{Hg}$ in air, in the early 1970 s the plant began collecting urinary $\mathrm{Hg}$ samples from employees, on about a quarterly basis. Although urinary samples were collected and analyzed, correction for dilution of urine with either creatinine or specific gravity was not performed until 1988. As uncorrected values can lead to extensive misclassification, the uncorrected urinary data were not used in this study. Also, the handwritten records of urinary $\mathrm{Hg}$ values for some of the time intervals were sloppy, and lacked any reference to quality control procedures or standardisation. Such data were also judged unusable. However, there were 590 urinary $\mathrm{Hg}$ values from November 1988 to the end of May 1991 that were corrected for specific gravity and seemed to have been rigorously measured and recorded. These data came from 78 workers representing 13 of the 16 exposure groups in table 1 . For each of the 78 workers, we identified the start and end date of the available urinary readings, and averaged these readings. We then calculated the mean, cumulative, and peak exposures for the period beginning 60 days before the first urinary $\mathrm{Hg}$ reading and ending 60 days before the final urinary $\mathrm{Hg}$ reading, to account for the published half life of urinary $\mathrm{Hg}$ of $40-60$ days. $^{8}$ We compared the urinary values with each of the reconstructed exposures to $\mathrm{Hg}$ concentrations with Spearman correlation coefficients.

\section{CORRECTION FOR INTERFERENCE BY CHLORINE} GAS

At least one previous study ${ }^{9}$ found that chlorine gas interfered with UV detection instruments that made direct readings of $\mathrm{Hg}$. Chlorine gas can chemically interact with the elemental $\mathrm{Hg}$ vapour to form mercuric chloride, which is not detected by the UV method, causing negative interference. ${ }^{10}$ This negative effect has been found to be directly proportional to the amount of chlorine gas present.

Chlorine gas was continually present at the factory in our study, requiring occasional plant shutdowns due to chlorine releases and routine use of respiratory protection against chlorine. The precise concentrations of chlorine that were present are not known. The NIOSH investigators ${ }^{2}$ did perform some limited sampling of chlorine in air and found the air concentrations to be generally below $1.5 \mu \mathrm{g} / \mathrm{m}^{3}$ (six of seven samples). Workers were questioned about the presence of chlorine during our interview process and reported that personnel recording the $\mathrm{Hg}$ readings avoided areas where chlorine concentrations were noticeably irritating. The air concentration of chlorine gas that usually causes irritation is reported to be above $1.5 \mu \mathrm{g} / \mathrm{m}^{3} .{ }^{11}$ Accordingly, we assumed, based on the interviews and $\mathrm{NIOSH}$ findings, that the chlorine gas concentration was at or below this value when $\mathrm{Hg}$ readings were collected.

If interference by chlorine affected our $\mathrm{Hg}$ data, it would only have affected the area samples collected with the Bacharach Mercury Sniffer; the personal samples that were actively collected on sorbent tubes and later analyzed by atomic absorbtion would have been unaffected. To assess whether the direct reading sampling data were affected by the presence of chlorine, we sought to compare results from concurrent sampling methods. From the data recovered at the site, active personal samples were collected concurrently with area samples on only 8 separate days (table 2 ). We used the data from these days to perform a limited comparison between the personal active sampling data and the predicted TWA concentrations with the rank order correlation coefficient, a comparison of the relative order from low to high.

\section{Results}

\section{EXPOSURE ESTIMATES}

To measure exposure trends over time, the readings of $\mathrm{Hg}$ in air (about 25000 ) from throughout the site collected by factory personnel from 1967 to 1993 were sorted by year and annual means were calculated. These values ranged from about 5 to slightly above $100 \mu \mathrm{g} \mathrm{Hg} / \mathrm{m}^{3}$ of air. The concentrations increased over the years with the highest concentrations in air coming in the late 1980s and early 1990s. This finding confirmed the impressions of employees interviewed who thought that conditions at the site began to worsen in the early 1980 s and declined until the plant closed in 1994 .

The next step was to apply the TWA formulas to exposure groups and calculate annual estimates of exposure to $\mathrm{Hg}$. Figure 1 provides the annual estimates of exposure to $\mathrm{Hg}$ for cell room jobs (including $\mathrm{Hg}$ handler, cell repair/ assembly, and other cell room workers), the products areas exposure group, and a mean of the remaining 11 exposure groups grouped as "average of all other workers". Within each of these categories, the $\mathrm{Hg}$ concentrations began to increase in the late 1970s and remained high 


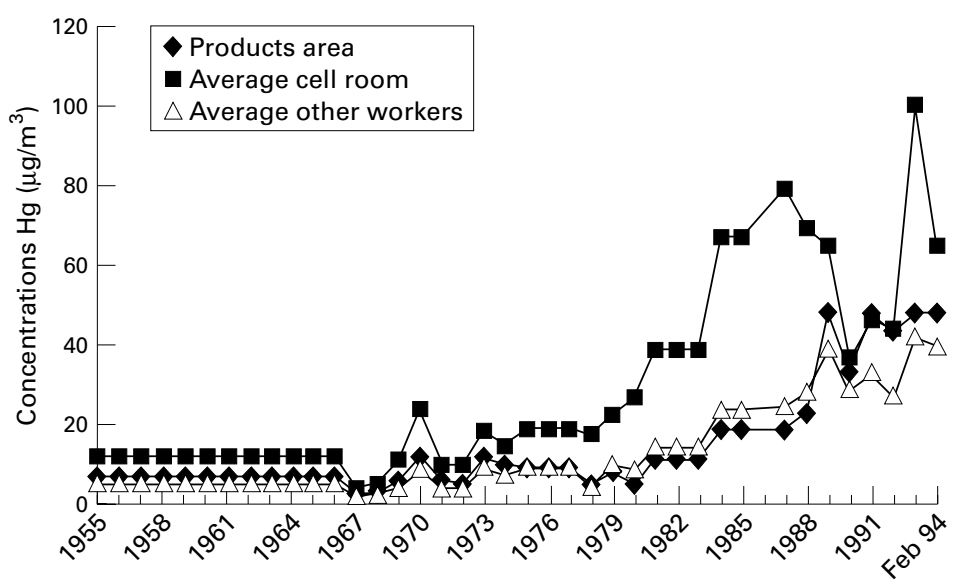

Figure 1 Annual mean estimates of exposure to $\mathrm{Hg}$ for peripheral areas of the factory.

until the factory closed in 1994. On average, the cell room personnel had the highest exposures to $\mathrm{Hg}$ of anyone in the factory, as expected based on employee interviews. Within the cell room, the $\mathrm{Hg}$ handlers and cell repair/assembly categories had the highest exposure to $\mathrm{Hg}$ concentrations (fig 2).

DATA VALIDATION

Each cell room contained 28 fans capable of each moving $908 \mathrm{~m}^{3}$ air/minute. The primary function of these fans was to cool the cell rooms, which reached temperatures of over $37^{\circ} \mathrm{C}$. With the heat produced by the process and the warm climate of Brunswick, Georgia, most of the fans were operated during most of the year. At times when the outside temperatures were unusually low, some of the fans would be turned off, but even then it was reported that at least two fans would always be running. Based on a range of two to 28 fans in operation, moving an estimated $2.6 \times 10^{6}$ to $3.7 \times 10^{7} \mathrm{~m}^{3}$ air through the room daily, the rough volume of $23391 \mathrm{~m}^{3}$ for the building, and an expected daily loss of $0.57 \mathrm{~kg} \mathrm{Hg}$ in each cell room, the predicted concentration of $\mathrm{Hg}$ in air in the cell rooms would range from about $15-220 \mu \mathrm{g} \mathrm{Hg} / \mathrm{m}^{3}$ air with the lower end of the range representing more dilution from

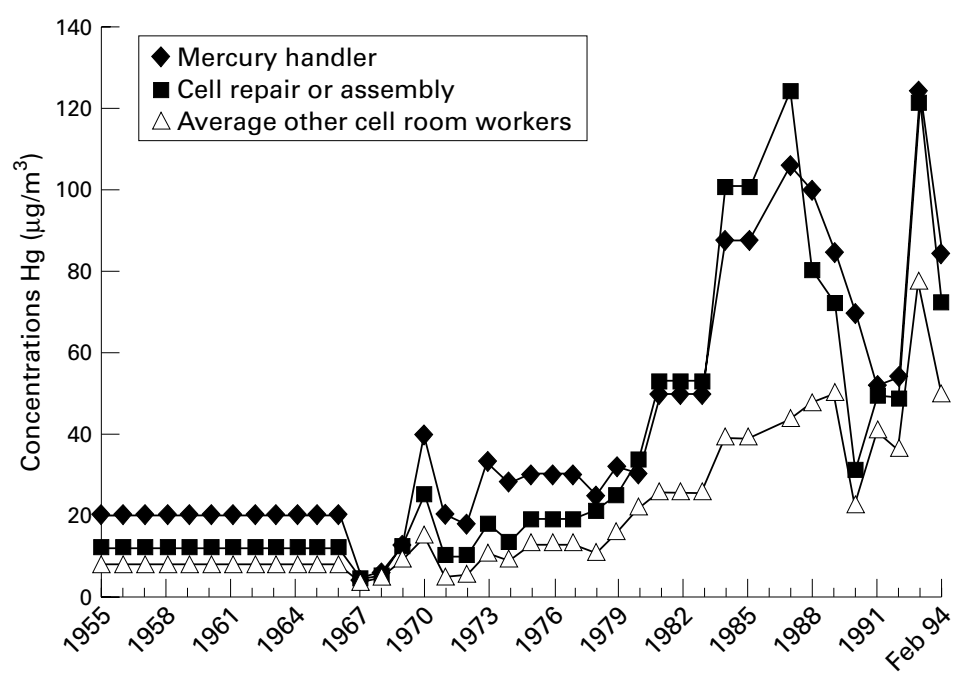

Figure 2 Annual mean estimates of exposure to $\mathrm{Hg}$ for employees within the cell room. outside air (operation of all 28 fans) and the higher end representing less dilution (only two fans operating). The actual exposures of employees would be affected by many thingssuch as the amount of time spent in the cell room, the air mixing conditions in the room, the work activities, the actual amount of $\mathrm{Hg}$ released, and the operating condition of the fans. None the less, the calculated range corresponds well to the TWAs estimated for cell room employees (fig 2).

There were 78 former workers for whom data on urinary Hg during 1988-91 were available, and for whom we reconstructed job histories and associated exposures. These 78 workers had mean urinary $\mathrm{Hg}$ concentrations of $72.4 \mu \mathrm{g} / 1$, with a range of $13.0-191.5 \mu \mathrm{g} / \mathrm{l}$ (corrected to a specific gravity of 1.024). The Spearman correlation coefficients were 0.52 for the mean exposure, 0.69 for the cumulative exposure, and 0.74 for the maximum exposure, all with $\mathrm{p}<0.0001$. One previous study ${ }^{12}$ reported that data on urinary $\mathrm{Hg}$ are the best predictors of exposure to $\mathrm{Hg}$ and these values indicate that our exposure estimates are reasonable predictors of exposure to $\mathrm{Hg}$.

\section{CORRECTION FOR INTERFERENCE BY CHLORINE}

GAS

As shown in table 2, the active, personal samples always yielded a higher $\mathrm{Hg}$ concentration than the predicted TWA from the concurrent direct reading area sample but they have a similar trend (higher active samples correspond to higher predicted TWA Hg concentrations). The rank order correlation coefficient for the data is $0.85(\mathrm{p}<0.01)$ and the Pearson's correlation coefficient is 0.60 . Based on these findings it was assessed that the estimated exposure of an employee to $\mathrm{Hg}$ to be used in the concurrent epidemiology study should be increased to account for the potential interference by chlorine gas. Smith et $a l^{9}$ found that concentrations of chlorine in air in the 1.5 $\mathrm{mg} / \mathrm{m}^{3}$ range (concentration of chlorine in air associated with irritation) resulted in about a $20 \%$ reduction in the concentrations of $\mathrm{Hg}$ in air recorded by the instruments thar read $\mathrm{Hg}$ concentrations directly. As this concentration of chlorine in air is thought to be the upper range of exposure to chlorine in the area where $\mathrm{Hg}$ readings were taken, the estimates of exposure to $\mathrm{Hg}$ were increased by $20 \%$.

This alteration results in the cell room $\mathrm{Hg}$ concentration increasing to a range of 18-147 $\mu \mathrm{g} / \mathrm{m}^{3}$. These increased values were used in the concurrent epidemiology study ${ }^{1}$ and individual exposure estimates for mean, cumulative, and peak concentrations were derived. These exposures were consistent with values reported from other chloralkali factories ${ }^{10-14}$ and well within the range predicted from rates of change of $\mathrm{Hg}$ in air, and do not affect the correlation with urinary data of the employees.

\section{Discussion}

Only one recent study ${ }^{12}$ reports exposures to $\mathrm{Hg}$ in a chloralkali factory and several older studies also were identified. ${ }^{10}{ }^{13-15}$ With the older studies, area sampling data of air were 
primarily collected with instruments that took direct readings - such as the Bacharach Mercury Sniffer - supplemented with some limited personal air samples (very similar to our data). The most recent study ${ }^{12}$ was performed for an exposure period 1990-7 and used personal sampling data. The cell room TWA concentrations of $\mathrm{Hg}$ in air for the older studies were reported to be $80-110 \mu \mathrm{g} / \mathrm{m}^{3}$ for two United States plants $(1957-62)^{13}$; a range of $1-270$ $\mu \mathrm{g} / \mathrm{m}^{3}$ with $60 \%$ at or below $50 \mu \mathrm{g} / \mathrm{m}^{3}$ for 21 operations in the United States and Canada in the late $1960 \mathrm{~s}^{9}$; generally between 50 and 100 $\mu \mathrm{g} / \mathrm{m}^{3}$ for the high exposure groups from two North American factories in the middle to late $1970 \mathrm{~s}^{14}$; and usually between 30 and $90 \mu \mathrm{g} / \mathrm{m}^{3}$ with a mean of $75 \mu \mathrm{g} / \mathrm{m}^{3}$ in two German plants (1976-7). ${ }^{15}$ The recent study reported that the cell room maintenance workers had the highest exposures to $\mathrm{Hg}$ but provided only an overall mean (SD) factory exposure level for all employees of 22 (35) $\mu \mathrm{g} / \mathrm{m}^{3} .^{12}$ The years covered in the older studies - early 1960s to early 1980 s - should represent similar working conditions present within the chloralkali industry. In our study, during these same years a range of about $15-40 \mu \mathrm{g} / \mathrm{m}^{3}$ TWA $\mathrm{Hg}$ concentrations (or about $20-50 \mu \mathrm{g} / \mathrm{m}^{3}$ when corrected for chlorine) was estimated for cell room employees, which is at the low end of the range reported in other studies.

Our study found a much higher exposure to $\mathrm{Hg}$ in the later years of the factory's operation (late 1970s to closure in 1994) compared with the earlier years of operation. One might conclude from the data that the exposure estimates represent two separate data sets that may have resulted due to differences in monitoring $\mathrm{Hg}$ or from increased interest from outside agencies causing improved monitoring methods at the site. We do not think that this was the case. The work force at the site was stable and the $\mathrm{Hg}$ monitoring was performed by basically the same group of workers with the same instrument and methods. Also, exposure to $\mathrm{Hg}$ started to increase in the late 1970 s and steadily rose with the highest exposures in 1987, before the inquires by governmental agencies. In fact, it seems that the concentrations improved for several years (1988-91) after outside interest from governmental agencies. For these reasons, we think that the estimates represent actual exposures to $\mathrm{Hg}$ over the course of the factory's operation.

This paper shows the systematic historical reconstruction of past exposures for use in an epidemiological study. As in many such efforts, we had to rely on several types of data, including air sampling, measurements of urinary $\mathrm{Hg}$, and recollections of former workers. Much of the primary data had not been published, existed in the form of handwritten records in dusty boxes, and was of unclear quality. Hence, an important initial challenge was to assess the quality of the data. We initially planned to use all available data on urinary $\mathrm{Hg}$, but on inspection, we were not confident in the quality of most of these data. Such judgments are an important aspect of reconstruction of historical exposure.
It is important to note that our exposure estimates are based on concentrations in air. However, actual exposures could have been higher due to dermal absorption. Biomarkers of exposure, when available, integrate different routes of exposure, offering an important advantage over workplace sampling of a specific medium.

Two aspects of this process are noteworthy. Firstly, we attempt to validate our reconstructed exposures in two ways: through modelling concentrations of $\mathrm{Hg}$ in air, and through comparison with concentrations of urinary $\mathrm{Hg}$. Both approaches were straightforward and feasible with the available data (albeit a truncated urinary $\mathrm{Hg}$ data set), and both confirmed the results of our reconstruction. We recommend such efforts as validation in historical assessment of exposure. Symanski et al ${ }^{12}$ compared data on exposures of $\mathrm{Hg}$ in air, blood $\mathrm{Hg}$, and urinary $\mathrm{Hg}$, and found that creatinine corrected urinary $\mathrm{Hg}$ better discriminated worker's exposures than the other two. In our study data on urinary $\mathrm{Hg}$ were too limited to use (except as described above) and concentrations of $\mathrm{Hg}$ in air had to be used as the principal exposure estimate.

Secondly, we considered the issue of interference with direct readings of $\mathrm{Hg}$ by chlorine. This phenomenon, although well established, has not been considered in previous studies. Although it did not result in major changes in our exposure estimates, such corrections could be important in calculating dose-response relations.

Electromagnetic fields associated with the Solvay process may also interfere with direct reading measurements of $\mathrm{Hg}$, but this interaction is less clear, and the effect may be positive or negative. The NIOSH investigators ${ }^{2}$ did perform measurements of electromagnetic fields at the site and found levels ranging from $0-0.05 \mathrm{~T}$ with most being less than $0.01 \mathrm{~T}$, all of which are within acceptable occupational exposure levels. The interviews of the employees showed that the Bacharach Mercury Sniffers were always zeroed and checked for calibration outside the cell rooms, which should have limited any interference from electromagnetic fields.

In conclusion, this paper provides a detailed description of a historical reconstruction of occupational exposure to $\mathrm{Hg}$ in a chloralkali plant over nearly 40 years of exposure, with area readings from an instrument that reads $\mathrm{Hg}$ directly, supplemented by limited data on personal sampling and urinary $\mathrm{Hg}$. The $\mathrm{Hg}$ concentrations were found to be highest in the cell room where some job categories had peak air concentrations above $145 \mu \mathrm{g} / \mathrm{m}^{3}$. The estimates of exposure in air correlate with data on urinary $\mathrm{Hg}$ of the employees and are well within the range of $\mathrm{Hg}$ data predicted from rates of change of $\mathrm{Hg}$ in air and from other studies from similar processes.

This study was funded by Grant 1 RO1 ES08346 from the National Institute of Environmental Health Science. 
1 Frumkin H, Letz R, Williams PL, et al. Health effects of long-term mercury exposure among workers in a chlorallong-term mercury exposure among worke
kali plant. Amer 7 Ind Med 2001; (in press).

2 Reh CM, Deitchman SD, Moss CE. Health hazard evaluation report. Brunswick, GA: LCP Chemicals and Plastics, Bethesda, MD: US DHHS/CDC/NIOSH, 1991. (Publ No HETA 87-402-2145.

3 Gidel RD. Occupational Safety and Health Administration air sampling worksheets from LCP Chemicals and Plastics, Inc, Brunswick, GA. Savannah, GA: USDOL/OSHA, 1987. (Inspection No 101859858, USDOL/OSHA, (OSHA-91A forms).)

4 Gidel RD. Occupational Safety and Health Administration air sampling worksheets from LCP Chemicals and Plastics, Inc, Brunswick, GA. Savannah, GA. USDOL/OSHA, 1990. (Inspection No 17402744, USDOL/OSHA, (OSHA-91A forms).)

5 Gidel RD. Occupational Safety and Health Administration air sampling worksheets from LCP Chemicals and Plastics, Inc, sampling worksheets from LCP Chemicals and Plastics, Inc, (Inspection No 109005108, USDOL/OSHA, (OSHA-91A (Inspections).)

6 Stopford W. Occupational health evaluation of LCP Chemicals Stopford W. Occupational health evaluation of LCP Chemicals
and Plastics, Inc, Brunswick, $G A$ [letter to the facility]. Durham, NC: Duke University Medical Center, 1988.
7 Williams PL, Luster MT, Middendorf PJ. Area sampling methods: selecting the proper sites. Occup Health Safety 1983;55:21-4.

8 Ellenhorn MJ, Barceloux DG. Medical toxicology. New York: Elsevier, 1988:1049

9 Smith RG, Vorwald AJ, Patil LS, et al. Effects of exposure to mercury in the manufacture of chlorine. Am Ind Hyg Assoc f 1970;31:687-700.

10 Skare I, Johansson R. Reactions between mercury vapor and chlorine gas at occupational exposure levels. Chemosphere 1992;24:1633-44.

11 American Conference of Governmental Industrial Hygienist. Documentation of the threshold limit values and biological exposure indices, 6th ed. Cincinnati: ACGIH, 1991:252-5.

12 Symanski E, Sallsten G, Barregard L. Variability in airborne and biological measures of exposure to mercury in the chloralkali industry: implications for epidemiologic studies. Environ Health Perspect 2000;108:569-73.

13 McGill CM, Ladd AC, Jacobs MB, et al. Mercury exposure in a chlorine plant. 7 Occup Med 1964;6:335-7.

14 Bunn WB, McGill CM, Barber TE, et al. Mercury exposure in chloralkali plants. Am Ind Hyg Assoc f 1986;45:249-54.

15 Schuckmann F. Study of preclinical changes in workers exposed to inorganic mercury in chloralkali plants. Int Arch Occup Environ Health 1979;44:193-200.

\section{Vancouver style}

All manuscripts submitted to Occup Environ Med should conform to the uniform requirements for manuscripts submitted to biomedical journals (known as the Vancouver style.)

Occup Environ Med, together with many other international biomedical journals, has agreed to accept articles prepared in accordance with the Vancouver style. The style (described in full in the $f A M A[1]$ ) is intended to standardise requirements for authors, and is the same as in this issue.

References should be numbered consecutively in the order in which they are first mentioned in the text by Arabic numerals on the line in square brackets on each occasion the reference is cited (Manson[1] confirmed other reports[2][3][4][5]). In future references to papers submitted to Occup Environ Med should include: the names of all authors if there are three or less or, if there are more, the first three followed by et al; the title of journal articles or book chapters; the titles of journals abbreviated according to the style of Index Medicus; and the first and final page numbers of the article or chapter. Titles not in Index Medicus should be given in full.

Examples of common forms of references are:

1 International Committee of Medical Journal Editors. Uniform requirements for manuscripts submitted to biomed journals. $7 A M A$ 1993;269:2282-6.

2 Soter NA, Wasserman SI, Austen KF. Cold urticaria: release into the circulation of histmaine and eosinophil chemotactic factor of anaphylaxis during cold challenge. N Engl F Med 1976;294:687-90.

3 Weinstein L, Swartz MN. Pathogenic properties of invading micro-organisms. In: Sodeman WA Jr, Sodeman WA, eds. Pathologic physiology, mechanisms of disease. Philadelphia: W B Saunders, 1974:457-72. 